\title{
I УКРАЇНО-БРИТАНСЬКИЙ ФОРУМ «ДОСКОНАЛІСТЬ ВИКЛАДАННЯ І НАВЧАННЯ У ВИЩІЙ ОСВІТІ»
}

4 грудня 2019 р., м. Київ, Україна

https://doi.org/10.37472/2707-305X-2019-1-1-3-7

I Україно-британський форум «Досконалість викладання і навчання у вищій освіті» відбувся 4 грудня 2019 р. Організаторами Форуму виступили: Британська Рада в Україні, Інститут вищої освіти НАПН України та Advance HЕ (Велика Британія) за підтримки Міністерства освіти і науки України та Національного агентства забезпечення якості вищої освіти.

Участь у конференції взяли 133 особи представники понад 90 закладів вищої освіти України, інституцій Великої Британії, Міністерства освіти і науки України, Національного агентства забезпечення якості вищої освіти та ін.

3 вітальним словом до учасників конференції звернувся Саймон Вільямс, директор Британської Ради в Україні.

у межах Cесії 1 «Досконалість викладання як пріоритет розвитку Європейського простору вищої освіти та національної політики в Україні» свої експертні позиції представили:

- Світлана Калашнікова, директор Інституту вищої освіти НАПН України, член Національної команди експертів з реформування вищої освіти - доповідь «Досконалість викладання як пріоритет розвитку Європейського простору вищої освіти»;

- Олег Шаров, генеральний директор Директорату вищої освіти і освіти дорослих Міністерства освіти і науки України, член Національної команди експертів з реформування вищої освіти - доповідь «Досконалість викладання: законодавство і практика»;

- Михайло Винницький, керівник секретаріату Національного агентства із забезпечення якості вищої освіти, член Національної команди експертів 3 реформування вищої освіти доповідь «Досконалість викладання у планах Національного агентства із забезпечення якості вищої освіти».

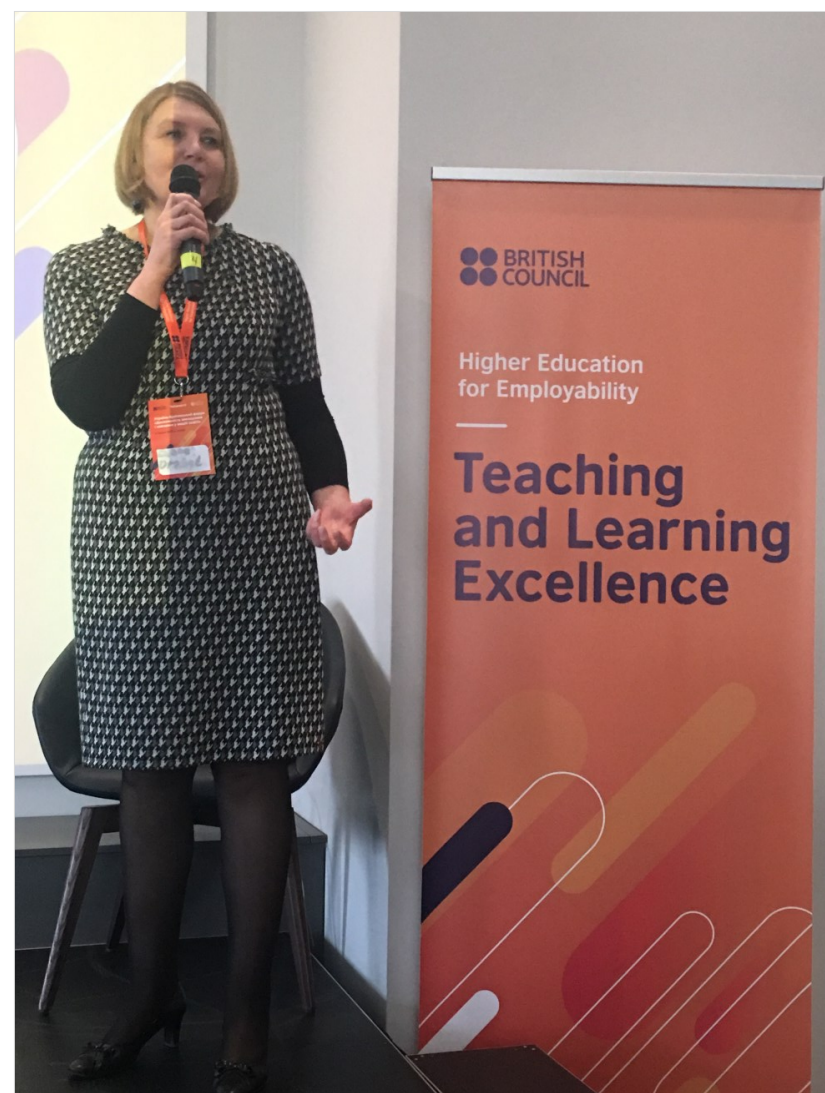

У межах Сесії 2 досвід Великої Британії щодо вдосконалення викладання у вищій освіті презентували Ієн Холл, керівник партнерських програм, Advance HE (Велика Британія) та Джулі Болдрі Карренс, генеральний директор Higher Ideas (Велика Британія).

Досвід університетів України щодо професійного розвитку викладачів представили:

- Володимир Бугров, проректор з науковопедагогічної роботи Київського національного університету імені Тараса Шевченка;

- Наталія Віннікова, проректор з наукової роботи Київського університету імені Бориса Грінченка; 
- Тарас Добко, перший проректор Українського католицького університету, член Національної команди експертів з реформування вищої освіти.

Окрім того, під час Форуму були презентовані результати дослідження щодо стану і потреб у викладанні і навчанні у вищій освіті України (Юлія Соболь, менеджер освітніх проєктів Британської Ради в Україні). Важливим акцентом Форуму стала презентація нової трирічної Програми вдосконалення викладання у вищій освіті України (Ukraine Higher Education Teaching Excellence Programme), яку представили Людмила Таценко, керівник відділу освітніх проєктів Британської Ради в Україні та Світлана Калашнікова, директор Інституту вищої освіти НАПН України, член Національної команди експертів з реформування вищої освіти.

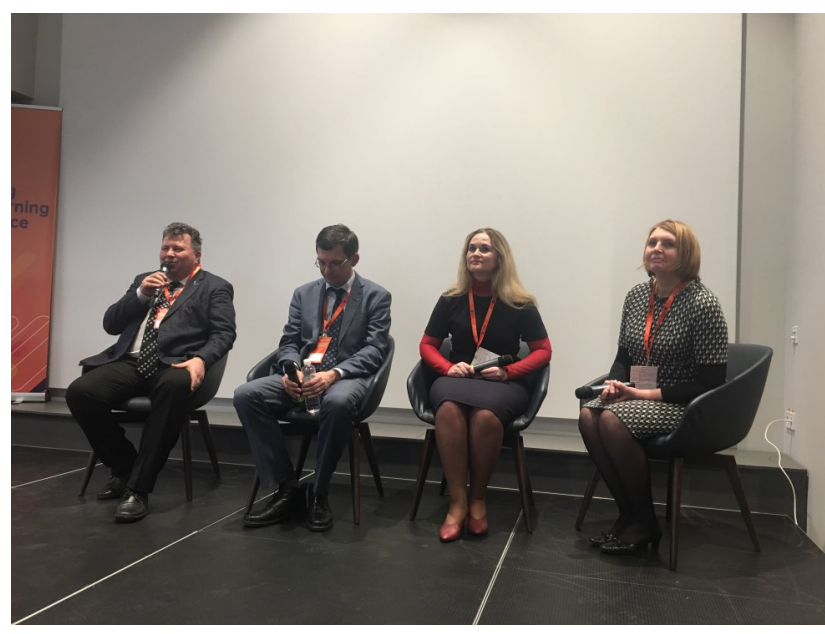

Усі матеріали Форуму розміщено на вебсайті Інституту вищої освіти НАПН України за посиланням.

КАЛАШНІКОВА Світлана Андріївна доктор педагогічних наук, профессор, член-кореспондент НАПН України, директор Інституту вищої освіти Національної академії педагогічних наук України, м. Київ, Україна

\section{UKRAINE-UK FORUM “TEACHING AND LEARNING EXCELLENCE IN HIGHER EDUCATION” \\ December 4, 2019, Kyiv, Ukraine}

Svitlana Kalashnikova

DSC in Education, Professor, Corresponding Member of NAES of Ukraine, Director, Institute of Higher Education of the National Academy of Educational Sciences of Ukraine, Kyiv, Ukraine

Abstract. Ukraine-UK Forum "Teaching and Learning Excellence in Higher Education" was held December 4, 2019. Among the forum organizers were: British Council Ukraine, Institute of Higher Education of the National Academy of Educational Sciences of Ukraine and Advance HE (Great Britain) supported by the Ministry of Education and Sciences of Ukraine and National Agency for Higher Education Quality Assurance (Ukraine).

133 representatives of more than 90 higher education institutions of Ukraine, institutions of Great Britain, Ministry of Education and Sciences of Ukraine, National Agency for Higher Education Quality Assurance (Ukraine), etc. participated within the forum.

Key words: higher education; teaching; learning; excellence; forum. 